that the higher portions of the ridges tend to rise to a certain level, which, on being connected by an imaginary plane, form a gently-sloping surface over a considerable area, it may be of hundreds or thousands of square miles in extent. Now, if in addition to this we insert the stratification of the district crossed by the section, and taken from actual observation, it will often be found that this imaginary plane is formed of the truncated edges of highly-inclined strata, or of the denuded summits of anticlinal arches of contorted or folded strata. When such strata are of hard and tough materials it is clear that they must have been planed down by an agent of great power and of long-continued action, but the result has been to convert originally highly uneven surfaces of flexured strata into approximately horizontal surfaces, over which inequalities have been worn off. Through such planes the existing river-valleys have been cut down, but between neighbouring valleys there is to be found the intervening ridge, trending upwards to the original, now imaginary plane. The Silurian district of Central Wales offers a remarkable example, which has been used by Prof. Ramsay ("Mem. Geol. Survey," vol. i.). Let any one on reaching the summit of one of the long ridges to the south of Cader Idris place his head on the ground, and in this position survey the tract of hilly country lying to the southwards, and he will realise the nature of the plane surface, out of which the valleys have been hollowed. But there are many more remarkable instances even than this. The central plain of Ireland is an example on a larger scale, over which the Middle and Upper Carboniferous rocks have been swept away, leaving a floor of limestone; but it would be impossible to explain the course of its great river, the Shannon, without referring its origin to a time when a sloping plain stretched from the present sources of that river amongst the Leitrim Hills to Shannon harbour below Limerick, because now its channel traverses a ridge of Old Silurian rocks at Killaloe, which could not have existed as such when the river first commenced to run over a tract formed of Carboniferous beds since denuded. But it is amongst mountainous districts that the evidence of the former existence of old planes is most remarkable, because least expected. The higher ridges of the Grampians seen at a distance, or accurately drawn from a hypothetical standpoint (as on Mr. Knipes' panoramic picture), forcibly bring home this idea to the mind. The ridges and peaks with very few exceptions tend to rise to an imaginary plane connecting the higher elevations, while several actual terraces coincide with the plane itself. Out of this old plane the existing valleys have been cut down, during the vast period of time descending from the pre-Devonian to the present. A still more ancient plane was that in which the Cambrian sandstones and conglomerates were strewn, formed of tough gneiss and hornblendic schists, with a gentle rise towards the east. The Scandinavian Promontory offers an illustration on a grand scale, and to these we might add the pre-Triassic plane formed of the denuded Devonian and Carboniferous rocks of Belgium and the Rhine highly tilted, convoluted, and contorted, through which the existing rivers have carved out their channels. But I refrain from adding additional illustrations, as I must pass to the consideration of the question, How have such ancient planes been formed? Where was the agent capable of abrading down bundreds or thousands of feet of the most obdurate rocks over hundreds or thousands of square miles, and of transporting power sufficient to carry away the débris of these vast ruins? The geologist answers, "Only give me an unlimited time, and the waves, tides, and currents of the seas acting along the coast-lines as they at present act, will effect all that you demand." Granted that with "unlimited " time all this may be effected, but this is a demand which the astronomers will not concede, and geologists must pay some respect to astronomers and mathematicians after all. But even with the aid of (practically) "unlimited" time a serious objection meets us at the threshold. It is undeniable that the crust of the earth is always on the move, either upwards or downwards ; those who are not intensely uniformitarian in their views contend that this oscillatory motion of the crust was much more rapid in past geological times than at the present day. If this be admitted, and I hold that it is a necessary consequence of the constantly decreasing rapidity with which the secular cooling of the surface has progressed downwards to the present day, how, let me ask, are you to get the coast to remain sufficiently long within range of such wave action as we see at present, to admit of the abrasion of the land to any considerable distance. The effects of wave action along our existing coasts, where formed of the more solid strata, is admittedly very slow, and in order to produce any great planing effects, the same coast-level (approximately) must be presented to it for a lengthened period; but with the required (practically) "unlimited" time, the coast-level would be placed out of reach, either by elevation or submergence. The hypothesis of approximately unlimited time seems to me, therefore, to be untenable. And what we require is not time but force, in order to account for the planing away of vast masses of obdurate strata over extensive areas. Such additional force Prof. Ball has supplied us with. He has shown that at a comparatively early stage of geological history the tides may have had a denuding effect several hundred times more powerfui than the present. With such a "stupendous tidal grinding-engine" we may indeed conceive the work we have to account for accomplished, and the hypothesis of Prof. Ball approaches certainty, when it is considered that the character of the floors of the sea adjoining our coastlines gives but slight evidence that such planes of marine denudation as I have attempted to describe, are in course of formation at the present day. They are phenomena of the past, not of the present, when wave and tidal action has, happily for mankind, subsided into restricted limits as compared with that of Palæozoic and Mesozoic times. EDWARD HULI

\section{TELEGRAPHS IN CHINA}

$\mathrm{N}$ December 2 a telegram was received from Reuter's agent at Shanghai, announcing that the telegraph line between that town and Tientsin was finished. In a few weeks we may expect to hear of the completion of the line to Peking. The capital of the Chinese empire, the chief seat of bigotry and hostility to foreign innovation, will then be in direct communication with Europe and America. There is, we believe, no doubt in the minds of those acquainted with the origin of this undertaking, that political motives alone dictated it. Hitherto, durings the winter, when the mouth of the Peiho was closed by ice, couriers taking from twenty to thirty days on the journey travelled down the Grand Canal to the Yangtsze conveying letters to Shanghai; or they were sent across Manchuria, in from fifteen to twenty days to Kiachta, where they reached the Great Northern Telegraph Company's Siberian lines. These slow and uncertain modes of communication with the outer world were severely felt by the Chinese Government during the winters of 1879 and 1880 , when its relations were almost broken off with Russia, when the land and sea forces of the latter were hanging like a thundercloud on the frontiers of China, and a peaceable solution of the Kuldja question seemed impossible. It was then brought home to the Peking authorities that their coasts might be invaded, their principal cities captured, and the foe be almost at their gates weeks before they heard the news. The bitter experience of these years taught the Chinese a hard lesson, but one which they speedily took to heart. Long before the Marquis Tsêng brought the question to a 
peaceable conclusion the Chinese Government had ordered large quantities of telegraph material from England, and within a few months of the ratification of the treaty with Russia, we find the port of Peking connected by telegraph with the rest of the world. The Chinese may occasionally be slow in their mental processes, but the present instance shows that when once the utility of an innovation is clearly presented to their minds, they seize and assimilate it with a rapidity worthy of their more mercurial neighbours, the Japanese; and this, it will be observed, is as true of the Government as of individuals.

It is not yet known how far the new lines will be open for public use ; but, judging by the rapid spread of other foreign inventions in China when once introduced, we cannot be far wrong in anticipating a vast extension of the telegraph for all purposes in that country. Ten or twelve years ago there was hardly a Chinese-owned steamer engaged on the coasts or inland waters of the empire ; 84 per cent. of this trade is now carried on in Chinese bottoms. Large and well-appointed steamers, Chinese-owned and manned, now ply to every port along the coast and on the Yang-tsze. As we write, a Chinese steamer has arrived in the Thames, bringing several native merchants who are about to enter into competition with us on our own ground. From time to time we have recorded in NATURE the various stages in the progress of the new telegraph line, because it marks one of the most important steps that has ever been made in China towards the adoption of the results of Western science and civilisation. It is one of the very few improvements which she has adopted without external advice and pressure; in this instance she has sat at the feet of the best of all teachers, experience, and has profited by its precepts. Nor is the event any the less important when we reflect on the development possible for the other appliances of steam and electricity, now that the ice of dislike and distrust of innovation has been spontaneuusly broken. The intelligence and enterprise of the three hundred millions of the people of China will not long remain content with a single line of telegraph across a comparatively small corner of their vast territory. A race of men with strong mercantile instincts who seize with avidity on every time-or labour-saving appliance, the Chinese, now that their government has abandoned its most cherished prejudice, may well be expected to call for the extension of an invention such as the telegraph.

We may fitly conclude this attempt to forecast the future in China of one of the most remarkable productions of western science in the nineteenth century, by mentioning the lesson which may well be derived from our past intercourse with that country. It is worse than useless to thrust our improvements by force or threats on the Chinese. When left themselves to the results of their own experience and slow methods of thought, their advances, though occasionally tardy, are surer and more satisfactory. It can hardly be a matter for wonder that a people who have been taught to revere the teaching of their sages for nearly 3000 years as the highest products of human wisdom, and whose minds have been cast in the same mould from a period long anterior to our era, should look askance at the inventions of the modern man of science who knows nothing of the system of ethics and politics of Confucius and Mencius, and the other sages of antiquity. A few years ago a foreign company in China constructed, without the formal sanction of the Chinese authorities, a line of railway a few miles in length between Shanghai and Woosung, at the mouth of the Shanghai River. The government repeatedly called for the cessation of the traffic on the ground that its consent had not been obtained, and that it did not want railways in its territories. Finally, in order to prevent any complications respecting ownership, it purchased the line, destroyed it utterly, and sent the materials to Taiwan in Formosa, where, according to the latest accounts, they were lying rotting; and they did all this notwithstanding the arguments and protests of foreign ministers and diplomatists. They were determined at all cost to rid themselves of an innovation which had been thrust on them. On the other hand, a recent Peking Gazette published a memorial from the Governor-General of Shansi, one of the most powerful officials in the Empire, request. ing authority to lay down a line of railway to certain mines in his province. Preliminary surveys have already been made, and the memorialist goes so far as to demonstrate to the Emperor that had such a railway been in working order a few years ago, much of the misery and horrible loss of life in the Shantung famine might have been prevented. It is from bitter experiences such as these that the Chinese learn; the devices of diplomatists or promoters are thrown away on them.

\section{THE VOYAGE OF THE "VEGA"}

THE voyage of the $V e g a$ will be in many respects one of the most memorable events in the history of navigation. For the first time a continent has been circumnavigated, so far as authentic record goes, and at last the North-East Passage has been won, after heroic efforts begun nearly three and a half centuries ago. As Baron Nordenskjöld reminds us in these volumes, the North-West Passage, although explored, has never been navigated entirely by any ship, McClure's famous journey having been accomplished partly in sledges over the ice. But the voyage will be still more memorable by the two rich volumes in which it finds copious record, volumes which have scarcely a parallel in the whole literature of geographical exploration. For Baron Nordenskjöld has not contented himself with merely telling the story of his own successful voyage and its results. That voyage, as we have said, crowns the efforts of centuries, and it has been by the results of these efforts that the Vega bas accomplished her work with scarcely an adverse incident. It will be remembered that some six years ago Baron Nordenskjöld showed that the voyage from Norway to the mouth of the Yennissei could easily be accomplished in a week or two, if taken at the proper time. Since then trading ventures have gone over the course every year, and a regular trade-route may be held as established by the well-informed enterprise of the eminent Swedish professor. For something like twenty years Baron Nordenskjöld has been at work in the seas to the north of Europe, and mainly in Spitzbergen, and the rich results of them are known to all students of science, and their story was told about two years ago in an interesting work noticed in these pages. Thus he became probably more familiar with the ice-conditions of these northern seas than any other authority; and his success in the Yennissei expedition led him to think that there was no reason why the whole North-East Passage should not be navigated. But Baron Nordenskjöld is, above all, a man of science, and accustomed to go about his work in a scientific method. That he has the true spirit of adventure is proved by the work of half his lifetime, but then he has a weakness for entering upon his enterprises with his eyes open, of knowing where he is going, and what are likely to be the results to science. So before making up his mind about the North-East Passage, the Baron examined carefully all the records of previous voyages along the north coast of Europe and Asia, from the time of Othere, a thousand years ago, down to the latest adventures of the brave Norwegian skippers. Thus he found that at one time or other the whole of this stretch of coast had been navigated piecemeal, except the most northerly point of the old continent, Cape Chelyuskin,

I "The Voyage of the Vega round Asia and Europe; with a Historical Review of previous Jnurneys along the Notth Coast of the Old World." By A. E. Nordenskjöld. Translated by Alexander Leslie. Five steel portraits, numerous maps and illustrations. Two vols. (London : Macmillan and Co., $x \varepsilon 8 \mathrm{r}$.) 